\title{
Serum Interleukin-2 (IL-2) Levels in Untreated and Treated in Batak Tribe Patients with Schizophrenia
}

\author{
Julius Martin Siagian', Elmeida Effendy ${ }^{\mathbf{2}}$, Mustafa M. Amin ${ }^{3}$ \\ ${ }^{1,2,3}$ Department of Psychiatry, Faculty of Medicine, Universitas Sumatera Utara, Indonesia \\ siagianmjulius@gmail.com,micipsych@yahoo.com,noki4gozo@gmail.com
}

\begin{abstract}
To find out the difference of serum IL-2 levels between untreated and treated in the Batak tribe patients with schizophrenia and healthy control and also to find out the association between serum IL-2 levels with PANSS score in the Batak tribe patients with schizophrenia. This study was cross-sectional approach using a one-way ANOVA welch test and to find a correlation between serum IL-2 levels with PANSS score in the Batak tribe patients with schizophrenia which is conducted in Prof. Dr. M. Ildrem Psychiatric Hospital Medan and Dr. Pirngadi General Hospital Medan from September 2019-November 2019. Subjects of untreated were 55 subjects and treated in the Batak tribe patients with schizophrenia were 55 subjects and healthy control were 55 subjects. There were significant differences between these three groups using post hoc Games-Howell test on the value of $p<0.001$ and also been found there was a significant correlation between serum IL-2 levels with PANSS score in the Batak tribe patients with schizophrenia using the Pearson correlation test ( $r=0.599$, $p=0.001$ and $r=0.501, p=0.001$ ). It was founded that there were significant differences between serum IL-2 levels in three groups and also founded there was a significant correlation between serum IL-2 levels with PANSS score in the Batak tribe patients with schizophrenia.
\end{abstract}

Keywords

interleukin-2; patients with schizophrenia; PANSS

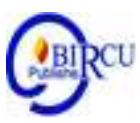

\section{Introduction}

Schizophrenia is a psychopathological clinical syndrome that tends to change, yet highly disturbing, involving cognition, emotions, perception and other aspects of behavior. This disorder usually begins before age 25, persists throughout life and affects people of all social classes. In the United States, the lifetime prevalence of schizophrenia is around 1 percent, which means that approximately 1 in 100 people will experience schizophrenia during their lifetime. ${ }^{1}$ Schizophrenia is a disease characterized by distortion of the mind, hallucinations and reduced ability to feel normal emotions, associated with immunity, environment and heredity. Although the exact cause of schizophrenia is unknown, a possible role of the immune system in the pathogenesis of schizophrenia has been indicated. ${ }^{2,3}$

Cytokines and other immune molecules are very important in the development and function of the central nervous system which are major actors in the maintenance of neuronal integrity, neurogenesis, synaptic deformities and nerve transmission. ${ }^{4}$ Several authors report immunological disorders in patients with schizophrenia, most studies 
focusing on plasma levels or production of mitogen-stimulated cytokines, such as interferon (IFN) $-\gamma$, interleukin (IL) -2 , IL-6 and tumor necrosis factor (TNF) $-\alpha$ in peripheral blood mononuclear cells (PBMC) and Th1/Th2 imbalance. ${ }^{2,5}$ Interleukins (IL)2 , IL- 6 and TNF- $\alpha$ mediate immune and inflammatory responses and activate cytokines that appear to play a key role in the central nervous system and are actively transported into the central nervous system, but are also released from glial cells which are activated. In patients with schizophrenia, elevated serum IL-2 levels have been observed and it has been found that IL-2 and IF- $\gamma$ production was significantly higher in patients with schizophrenia than controls. ${ }^{3,4}$ Atypical antipsychotics have been shown to reduce serum cytokines such as IL-2, IL-6 and TNF- $\alpha{ }^{4}$

A study conducted by Kim et al., in 2000, in South Korea, conducted a study on male patients with schizophrenia and healthy controls ( $\mathrm{n}=25$ each), using an experimental design and in that study measuring serum IL-2 in patients with schizophrenia blood, which showed significantly higher serum IL-2 levels in patients with schizophrenia compared to controls, with mean and standard deviation values of $2.7 \pm 1.8 \mathrm{pg} / \mathrm{ml}$ compared to $1.7 \pm 0.1$ $\mathrm{pg} / \mathrm{ml}(\mathrm{p}=0.007)$, also found a decrease in serum IL-2 levels in patients with schizophrenia before and after treatment, after 8 weeks of treatment with haloperidol, with mean and standard deviation namely $2.7 \pm 1.8 \mathrm{pg} / \mathrm{ml}$ versus $1.8 \pm 0.2 \mathrm{pg} / \mathrm{ml}(\mathrm{p}=0.02)$. Also found, a positive correlation of serum IL-2 levels with positive symptoms in patients with schizophrenia in the acute phase of the disease $(r=0.68, p<0.001){ }^{6}$ Also a study conducted by Zhang et al., In 2004, in Beijing (China ), conducted a study of 78 hospitalized patients diagnosed with chronic schizophrenia, with a clinical trial method consisting of 2 weeks of placebo and followed by 12 weeks of double-blindness, 78 patients were randomized to the risperidone group $(\mathrm{N}=41)$ or the haloperidol group $(\mathrm{N}=$ 37) and in that study found a significant difference in serum IL-2 levels in healthy controls with mean and standard deviation $(3.3 \pm 1.4 \mathrm{ng} / \mathrm{ml})$ and patients with schizophrenia before treatment $(9.6 \pm 5.2 \mathrm{ng} / \mathrm{ml})$ and after treatment $(6.7 \pm 4.6 \mathrm{ng} / \mathrm{ml})$ and also found a significant correlation between the rate of reduction in the total Positive and Negative Syndrome Scale (PANSS) and changes in serum IL-2 levels before and after treatment ( $\mathrm{r}=$ $0.38, \mathrm{p}=0.02) .{ }^{7}$ It was also shown that IL-2 may contribute to the pathophysiology of schizophrenia, especially to positive symptoms.

The results of this study suggest that both risperidone and haloperidol produced a positive symptom reduction effect, which may be attributed to the drug's effect at the same serum IL-2 levels. The finding of the study was that risperidone and haloperidol reduced serum IL-2 levels in schizophrenia, with no significant difference between the two drugs after 12 weeks of treatment (risperidone $7.2 \pm 4.9(\mathrm{p}=0.0015)$, haloperidol $6.1 \pm 4.3 . \mathrm{p}=$ $0.0011){ }^{7}$ In a study conducted by Tan and colleagues, in 2015 in Beijing (China), to assess serum IL-2 levels in a large group of 160 patients with schizophrenia compared with 60 healthy control subjects, age-matched and sex, it was found that serum IL-2 levels were significantly higher in chronic patients with schizophrenia than in healthy control subjects, with mean and standard deviation namely $6.7 \pm 2.2 \mathrm{ng} / \mathrm{ml}$ compared to $4.2 \pm 1.6 \mathrm{ng} / \mathrm{ml}$ (p < 0.0001). ${ }^{8}$ 


\section{Research Methods}

\subsection{Population and Demographic Studies}

This study is an unpaired numerical comparative analytical study of more than two groups with one measurement using a cross-sectional approach, which assesses the difference in serum IL-2 levels between untreated in the Batak tribe patients with schizophrenia (case group I), treated in the Batak tribe patients with schizophrenia (case group II) and the Batak tribe healthy control (control group). As well as assessing the relationship between serum IL-2 levels on PANSS scores in groups I and II. ${ }^{9}$ Where the selection of subjects in this study was using non-probability sampling, the type of consecutive sampling, which was conducted at Prof. Dr. M. Ildrem Psychiatric Hospital at the emergency room (ER) for case group I and at the inpatient installation for case group II and was also performed at Dr. Pirngadi General Hospital Medan in blood transfusion units for control group who have met the inclusion and exclusion criteria, in the period September 2019-November 2019.

Inclusion criteria for case group I include patients with schizophrenia diagnosed using Pedoman Penggolongan dan Diagnosis Gangguan Jiwa di Indonesia III (PPDGJ-III), aged 15-45 years, having a PANSS score of 90-150, dropping out of taking antipsychotic drugs for at least 2 weeks, duration of illness $\leq 5$ years, last education at least completing junior high school, and having ideal body weight $(\mathrm{BMI}=18.5-24.99)$, while the exclusion criteria included having general medical disorders with/without other comorbidities and having a history of substance use (except caffeine and nicotine). The inclusion criteria for case group II included patients with schizophrenia diagnosed using PPDGJ-III, aged 15-45 years, had received $4 \mathrm{mg}$ risperidone for 6 weeks, duration of illness $\leq 5$ years, last education had at least completed junior high school, had ideal body weight $(\mathrm{BMI}=18.5$ 24.99) and are available as respondents and can be interviewed, while the exclusion criteria include having general medical disorders with/without other comorbidities and having a history of substance use (except caffeine and nicotine). The inclusion criteria for the control group included no family history of psychiatric disorders, 15-45 years of age, the latest education at least completed junior high school, had ideal body weight (BMI = 18.5-24.99), and were willing to be respondents and could be interviewed, while the exclusion criteria were between others have general medical disorders with/without other comorbidities and have a history of substance use (except caffeine and nicotine).

\subsection{The Positive and Negative Syndrome Scale (PANSS)}

The Positive and Negative Syndrome Scale (PANSS) consists of 30 items with a subscale, namely 7 items are positive symptoms (examples of hallucinations and delusions), 7 items are negative symptoms (examples of blunt effect) and 16 items are general psychopathology (examples of guilt ). Each item is scored with 7 points with a Likert scale ranging from 1 to 7 , then the positive and negative subscales range from 7-49 and the general psychopathology scale ranges from 16-112. The Positive and Negative Syndrome Scale (PANSS) is used by trained clinicians and the time required ranges from 30-40 minutes. Each item from the PANSS is a complete definition as well as detailed criteria for all 7 assessment points that show improvement in psychopathology, namely: 1 = absent, $2=$ minimal, $3=$ mild, $4=$ moderate, $5=$ moderate-severe, $6=$ severe, $7=$ extreme. $^{10,11}$ 


\subsection{Procedure}

The blood collection procedure in case groups I, II and controls, which totaled 55 subjects for each groups, ${ }^{12}$ after fulfilling the inclusion and exclusion criteria was signing the research agreement, then carrying out a physical examination, vital sign and carrying out a body mass index examination by measuring height and weight. in each group. In the case group I, patients with anxious conditions, the patient is first injected with haloperidol $5 \mathrm{mg}$ (IM) and the patient must be under the supervision of medical personnel (if necessary, binding if the patient remains restless) and then blood draw is carried out in the ER of Prof. Dr. M. Ildrem Psychiatric Hospital and then assessed the PANSS score in the case group I. In the case group II, patient was fasted for at least 10-12 hours before taking blood and was carried out in the inpatient installation of Prof. Dr. M. Ildrem Psychiatric Hospital and then assessed the PANSS score in the case group II. In the control group, all healthy people who came to the blood transfusion unit at Dr. Pirngadi General Hospital Medan. Then prepare the tools and materials, give an identity label on the blood tube of the research subject, then use a handscoon and put a tourniquet at 3-4 inches from the puncture site, the subject is then asked to clench his palms until the veins are clearer, then clean the puncture site in the median vein. pinch the folds of the elbows with gauze and $70 \%$ alcohol cotton by turning from the inside out and letting the location dry. Then the needle pierces the medial cubital vein at a 45-degree angle with the needle facing upwards. Blood was allowed to flow into the syringe and while asking the subject to open his fist. Then the blood is drawn up to $3 \mathrm{ml}$ to check for IL-2. The tourniquet is removed, then the syringe is withdrawn while still pressing the insertion hole with an alcohol swab. The stabbing mark of the syringe was smeared with betadine and covered with a plaster. The blood tube was put into a cool box, then taken to the Faculty of Medicine, Universitas Sumatera Utara integrated laboratory for further processing to carry out a centrifuge to remove visible particulate matter and followed by checking the serum IL-2 levels using the Elisa Kit "Human Interleukin-2 ELISA Kit. Size 96 Wells Brands Bioassay TL”.

\subsection{Statistical Analysis}

The analytical test used in this study was the one-way ANOVA welch test followed by the Games-Howel post hoc test, in which to determine differences in serum IL-2 levels between untreated and treated in the Batak tribes patients with schizophrenia and healthy controls. Then continued with the Pearson correlation test to determine the relationship between serum IL-2 levels and the PANSS score in untreated and treated in the Batak tribes patients with schizophrenia. ${ }^{13,14}$ For data analysis using SPSS version 23.

\section{Results and Discussion}

\subsection{Results}

This study took 165 subjects, consisting of three groups of subjects, namely the case group I (untreated in the Batak Tribe patients with schizophrenia) as many as 55 subjects, the case group II (treated in the Batak Tribe patients with schizophrenia) as many as 55 subjects and the control group (the Batak Tribe healthy control) as many as 55 subjects, with the following demographic characteristics: 
Table 1. Demographic Characteristics in Untreated and Treated in The Batak Tribes Patients with Schizophrenia and Healthy Controls

\begin{tabular}{|c|c|c|c|c|}
\hline & $\begin{array}{c}\begin{array}{c}\text { Case Group I } \\
(\mathrm{n}=55)\end{array} \\
\end{array}$ & $\begin{array}{c}\begin{array}{c}\text { Case Group II } \\
(\mathrm{n}=55)\end{array} \\
\end{array}$ & $\begin{array}{c}\text { Control } \\
(\mathrm{n}=55)\end{array}$ & $\mathbf{P}$ \\
\hline \multicolumn{5}{|l|}{ Gender } \\
\hline Male & $35(63.6 \%)$ & $32(58.2 \%)$ & $36(65.5 \%)$ & \multirow[t]{2}{*}{$0.715^{\mathrm{b}}$} \\
\hline Female & $20(36.4 \%)$ & $23(41.8 \%)$ & $19(34.5 \%)$ & \\
\hline \multicolumn{5}{|l|}{ Age in year } \\
\hline \multicolumn{5}{|l|}{ Marital Status } \\
\hline Married & $19(34.5 \%)$ & $16(29.1 \%)$ & $25(45.5 \%)$ & \multirow[b]{2}{*}{$0.192^{\mathrm{L}}$} \\
\hline Unmarried & $36(65.5 \%)$ & $39(70.9 \%)$ & $30(54.5 \%)$ & \\
\hline \multicolumn{5}{|l|}{ Education Status } \\
\hline Low & $13(23.6 \%)$ & $13(23.6 \%)$ & $14(25.5 \%)$ & \multirow[t]{3}{*}{$0.415^{\mathrm{b}}$} \\
\hline Medium & $33(60.0 \%)$ & $28(50.9 \%)$ & $24(43.6 \%)$ & \\
\hline High & $9(16.4 \%)$ & $14(25.5 \%)$ & $17(30.9 \%)$ & \\
\hline \multicolumn{5}{|l|}{ Occupational } \\
\hline Status & $22(40.0 \%)$ & $16(29.1 \%)$ & $28(50.9 \%)$ & \multirow[t]{3}{*}{$0.065^{\mathrm{b}}$} \\
\hline Employed & $33(60.0 \%)$ & $39(70.9 \%)$ & $27(49.1 \%)$ & \\
\hline \multirow{2}{*}{\multicolumn{5}{|c|}{$\begin{array}{l}\text { Unemployed } \\
\text { BMI }\end{array}$}} \\
\hline & & & & \\
\hline mean $\pm \mathrm{sd}$ & $22.06 \pm 1.76$ & $21.99 \pm 1.71$ & $22.12 \pm 1.69$ & $0.928^{\mathrm{a}}$ \\
\hline $\begin{array}{l}\text { Duration of Ilness } \\
\text { median (min-max) } \\
\text { year }\end{array}$ & $3(1-5)$ & $3(1-5)$ & - & $0.052 *$ \\
\hline \multicolumn{5}{|l|}{ PANSS } \\
\hline $\begin{array}{l}\text { Positive scale } \\
\text { median (min-max) }\end{array}$ & $34(32-39)$ & $17(16-19)$ & - & - \\
\hline $\begin{array}{l}\text { Negative scale } \\
\text { median (min-max) }\end{array}$ & $27(21-32)$ & $13(10-16)$ & - & - \\
\hline
\end{tabular}

a One-way ANOVA Welch test

${ }^{\mathrm{b}}$ Pearson Chi-Square test

* Mann-Whitney U test

Table 1 shows the demographic characteristics of cases I, II and control groups. Both in case I, II and control groups, where most subjects from each group are male compared to female. In the case group I, 35 male subjects (63.6\%) and 20 female subjects $(36.4 \%)$. In the second case group, 32 subjects were male (58.2\%) and 23 female subjects $(41.8 \%)$. In the control group, as many as 36 male subjects (65.5\%) and 19 female subjects $(34.5 \%)$. Demographic data for gender were tested using the chi-square test, and the value of $\mathrm{p}=$ 0.715 (there was no significant difference between the three groups in gender). The demographic data for age for case group I are presented with mean and standard deviation of $29.91 \pm 5.56$, while for case group II with mean and standard deviation of $29.67 \pm 6.68$ and the control group with mean and standard deviation of $29.87 \pm 5.85$, these data are normally distributed. So that a one-way ANOVA welch test was carried out and the pvalue was obtained $=0.978$ (there was no significant difference between the three groups in age). In the demographic data for marital status for the case group I, the subjects who were married were 19 people $(34.5 \%)$ and 36 people were unmarried $(65.5 \%)$. In the case group II, the subject married as many as 16 people $(29.1 \%)$ and unmarried as many as 39 
people $(70.9 \%)$. In the control group, 25 people (45.5\%) were married and $30(54.5 \%)$ were unmarried. Demographic data for marital status was tested using the chi-square test, it was obtained p-value $=0.192$ (there was no significant difference between the three groups in marital status). In the demographic data for educational status in the case group I, the subjects with low education were 13 people (23.6\%), medium as many as 33 people $(60.0 \%)$ and high as many as 9 people $(16.4 \%)$. In the case group II, the subjects of low education were 13 people (23.6\%), medium as many as 28 people $(50.9 \%)$ and high as many as 14 people $(25.5 \%)$. In the control group, with low education subjects were 14 people $(25.5 \%)$, medium as many as 24 people $(43.6 \%)$ and high as many as 17 people (30.9\%). Demographic data for educational status was carried out by using the chi-square test and the value of $p=0.415$ (there was no significant difference between the three groups in educational status). In the demographic data for occupational status in the case group I, 22 people $(40.0 \%)$ employed and $33(60.0 \%)$ unemployed. In the case group II, the subject employed as many as 16 people $(29.1 \%)$ and unemployed as many as 39 people (70.9\%). In the control group, the subjects employed as many as 28 people $(50.9 \%)$ and unemployed as many as 27 people (49.1\%). Demographic data for occupational status performed by the chi-square test obtained $\mathrm{p}$-value $=0.065$ (there was no significant difference between the three groups in occupational status). In the demographic data for BMI in the case group I, it is presented with a mean and standard deviation $22.06 \pm 1.76$ and in the case of group II, with mean and standard deviation $21.99 \pm 1.71$ and the control group, with mean and standard deviation $22.12 \pm 1.69$, the data is normally distributed. So that the one-way ANOVA welch test was carried out and the $\mathrm{p}$-value was obtained $=0.928$ (there was no significant difference between the three groups in BMI). In the demographic data for the duration of illness in the case group I, with a median of 3 years and a minimum of 1 year-maximum 5 years and the case group II, with a median of 3 years and a minimum of 1 year-a maximum of 5 years. The data is not normally distributed and a test is performed to normalize the data, with a Log transformation before the comparison test is carried out, but it is still not normally distributed. Then the Mann-Whitney U test was performed for the duration of illness and the p-value was obtained $=0.052$ (there was no significant difference between the two groups in the duration of illness).

a. Differences in Serum IL-2 Levels between Untreated and Treated in Batak Tribe Patients with Schizophrenia and Healthy Control

In the data normality test above, it was found that the three data groups were normally distributed with $\mathrm{p}=0.20$ (Kolmogorov-Smirnov test). So it is continued with the one-way ANOVA welch test.

Table 2. Differences in Serum IL-2 Levels Between Untreated and Treated in The Batak Tribe Patients with Schizophrenia and Healthy Control

\begin{tabular}{llccc}
\hline & $\mathbf{N}$ & mean $(\mathbf{S . D}) \mathbf{n g} / \mathbf{m l}$ & p-value \\
\hline Serum IL-2 & Case Group I & 55 & $10.34(2.24)$ & $<0.001$ \\
& Case Group II & 55 & $5.53(1.05)$ & \\
& Control Group & 55 & $3.48(0.61)$ & \\
\hline
\end{tabular}

One-way ANOVA welch test

In table 2, a one-way ANOVA welch test was performed with a p-value $<0.001$. Because $\mathrm{p}<0.05$, it can be concluded that at least two groups have different variants. Then continued the Games-Howell post hoc test. 


\begin{tabular}{|c|c|c|c|c|}
\hline & \multirow[t]{2}{*}{ Mean Differences } & \multicolumn{2}{|c|}{ CI 95\% } & \multirow[t]{2}{*}{ p-value } \\
\hline & & $\min$ & $\max$ & \\
\hline $\begin{array}{l}\text { Case Group I vs Case } \\
\text { Group II }\end{array}$ & 4.81 & 4.01 & 5.61 & $<0.001$ \\
\hline $\begin{array}{l}\text { Case Group I vs Control } \\
\text { Group }\end{array}$ & 6.81 & 6.11 & 7.61 & $<0.001$ \\
\hline $\begin{array}{l}\text { Case Group II vs Control } \\
\text { Group }\end{array}$ & 2.05 & 1.66 & 2.44 & $<0.001$ \\
\hline
\end{tabular}

Games-Howell post hoc test. The number of subjects in each group was 55

Post hoc Games-Howell test with the mean difference between case group I vs case group II 4.81 and case group I vs control group 6.81 and case group II vs control group 2.05 with p-value $<0.001$ (there are very significant differences between the three groups).

\section{b. Correlation between Serum IL-2 Levels and PANSS Score in Untreated in Batak} Tribe Patients with Schizophrenia

In the data normality test, data were normally distributed using the KolmogorovSmirnov test $(\mathrm{p}=0.20)$.

Table 3. Correlation between Serum IL-2 Levels and PANSS Score in Untreated in Batak Tribe Patients with Schizophrenia

\begin{tabular}{lcccccc}
\hline Variable & mean & $\mathbf{\pm}$ & S.D & $\mathbf{p}$ & $\mathbf{r}$ & $\mathbf{N}$ \\
\hline IL-2 serum & 10.34 & \pm & 2.24 & & & \\
PANSS score & 104.47 & \pm & 10.46 & & & \\
& & & & 0.001 & 0.599 & 55 \\
\hline
\end{tabular}

Pearson correlation test

In table 3, for the correlation test of serum IL-2 levels and PANSS scores in untreated in the Batak tribe patients with schizophrenia, the Pearson correlation test is carried out, because the two data are normally distributed and the linearity requirements are met, the result of the correlation test is that the $r$-value is 0.599 with a $p$-value. $=0.001$ (significant correlation with positive correlation direction and moderate correlation), which means that the higher the serum IL-2 levels, the PANSS score will increase.

c. Correlation between Serum IL-2 Levels and PANSS Score in Treated in The Batak Tribe Patients with Schizophrenia

In the data normality test, data were normally distributed using the KolmogorovSmirnov test $(\mathrm{p}=0.20)$.

Table 4. Correlation between Serum IL-2 Levels and PANSS Score in Treated in Batak Tribe Patients with Schizophrenia

\begin{tabular}{lcccccc}
\hline Variable & mean & $\mathbf{\pm}$ & S.D & P & R & N \\
\hline IL-2 serum & 5.53 & \pm & 1.05 & & & \\
PANSS score & 54.64 & \pm & 8.73 & & & \\
& & & & 0.001 & 0.501 & 55 \\
\hline
\end{tabular}

Pearson correlation test 
In table 4, for the correlation test of serum IL-2 levels and PANSS scores in treated in the Batak tribe patients with schizophrenia, the Pearson correlation test is carried out because at least one of the variables to be correlated is normally distributed and the linearity requirements are met, then the correlation test results are obtained. While we obtained the $r$-value which is 0.501 with a value of $p=0.001$ (significant correlation with positive correlation direction and moderate correlation), it means that the lower the serum IL-2 levels, the PANSS score will decrease.

\subsection{Discussion}

In Table 1, the demographic characteristics of gender, most subjects are male than female, both in the case group I, case group II and the control group. There was no significant difference in gender between the three groups $(p=0.715)$. In the normality test of serum IL-2 levels and gender in the case group I of male, the mean was 10.13 and the standard deviation was 2.24, the female had a mean of 10.70 and a standard deviation of 2.24 (normally distributed), then continued with the unpaired T-test with p-value $=0.368$ (there was no significant difference between the two groups). In the PANSS score normality test and gender in the case group I for male, it was obtained a mean of 104.40 and a standard deviation of 11.35, for female a mean of 104.60 and a standard deviation of 8.97 (normally distributed), then continued with the unpaired T-test with p-value $=0.946$ ( there was no significant difference between the two groups). In the serum IL-2 levels normality test and gender in the case group II for male, the mean was 5.63 and the standard deviation was 1.13 , for female the mean was 5.37 and the standard deviation was 0.91 (normally distributed), then continued the unpaired T-test with $\mathrm{p}=0.367$ (there was no significant difference between the two groups). In the PANSS score normality test and gender in case group II in male, it was obtained a mean of 54.56 and a standard deviation of 7.54, for female a mean of 54.74 and a standard deviation of 10.33 (normally distributed), then continued the unpaired T-test with $\mathrm{p}$-value $=0.942$ (no there were significant differences between the two groups). In the normality test of serum IL-2 levels and gender in the control group in male, the mean was 3.45 and the standard deviation was 0.58 , for female the mean was 3.52 and the standard deviation was 0.65 (normally distributed), then continued the unpaired $\mathrm{T}$-test with $\mathrm{p}$-value $=0.669$ (there was no significant difference between the two groups). These results are following a study conducted by Tan et al., in 2015 in Beijing (China), conducted a study to assess serum IL2 levels in a large group of 160 patients with schizophrenia compared with 60 subjects in a healthy control group, that from the demographic data found There was no significant difference in gender between the patients with schizophrenia group and the healthy control group with a $\mathrm{p}$ value $>0.05$ and a two-way ANOVA test was conducted and found no significant difference in gender $(\mathrm{f}=0.05, \mathrm{df}=1.218, \mathrm{p}=0.82){ }^{8}$

The demographic characteristics of age for the case group I with mean and standard deviation of $29.91 \pm 5.56$, while for case group II with mean and standard deviation of $29.67 \pm 6.68$ and the control group with mean and standard deviation of $29.87 \pm 5.85$. This is by what was stated by Sadock et al., in 2015, in a book entitled Schizophrenia Spectrum and Other Psychotic Disorder, that the peak age of onset in men is earlier than in women. The peak age of onset for men is between 10-25 years and 25-35 years for women. Onset under 10 years or over 60 years is very rare. It is also said that the most common early onset of this disease is 15-30 years of age and is a chronic disease that disrupts patients and their families and has a major impact on their social and economic status. ${ }^{15}$

In the demographic characteristics of the marital status for the case group I, 19 people $(34.5 \%)$ were married and 36 unmarried people (65.5\%), for the case group II, 16 
people were married $(29.1 \%)$ and 39 unmarried people $(70.9 \%)$, for the control group who married 25 people $(45.5 \%)$ and 30 people $(54.5 \%)$ were unmarried, $\mathrm{p}=0.192$ (there was no significant difference between the three groups in marital status). This result is by a study conducted by Pinho et al., in 2017 in Portugal, which said that there were more patients with schizophrenia who were unmarried, namely 190 people $(67.4 \%)$, married 40 people (14.2\%), divorced 52 people $(18.4 \%) .{ }^{16}$

In the demographic characteristics of the educational status for the case group I, 13 people were low (23.6\%), 33 people were medium (60.0\%), and high was 9 people (16.4\%), for the case group II, the low was 13 people (23.6\%), medium as many as 28 people $(50.9 \%)$ and high as many as 14 people $(25.5 \%)$ and for the control group, low as many as 14 people $(25.5 \%)$, medium as many as 24 people $(43.6 \%)$ and high as many as 17 people $(30.9 \%), \mathrm{p}=0.415$ (there was no significant difference between the three groups in educational status). This result is by the study of Huang et al., in Shanghai (China), in 2018 it showed that the highest high school education level was in patients with schizophrenia, namely $39.5 \%(\mathrm{n}=43$ people $), 34.8 \%$ higher education $(\mathrm{n}=38$ people $)$ and junior high school $25.7 \%(\mathrm{n}=28$ people $) .{ }^{17}$

In the demographic characteristics of the occupational status for the case group I, 22 people $(40.0 \%)$ employed and 33 people $(60.0 \%)$ unemployed, for the case group II, 16 people $(29.1 \%)$ employed and 39 people $(70.9 \%)$ unemployed and for the control group, who employed as many as 28 people (50.9\%) and unemployed as many as 27 people $(49.1 \%), p=0.065$ (there was no significant difference between the three groups in occupational status). This result is following a study from Bowmans et al., in 2015 which stated that people with chronic mental illnesses, including schizophrenia, experience barriers to work due to stigma and discrimination. Other influencing factors include positive symptoms, negative symptoms, cognitive symptoms, treatment regimen, duration of illness, disease onset and substance abuse. Also in a study conducted by Pinho et al., in 2017 in Portugal, on the influence of sociodemographics on the quality of life of patients with schizophrenia, found data from 282 patients with schizophrenia, only 26 people $(9.2 \%)$ were either working or still in school, $90.8 \%$ others are said to be unemployed and unable to work. ${ }^{18,16}$

In the demographic characteristics of the body mass index (BMI) for the case group I with a mean and standard deviation of $22.06 \pm 1.76$ while in the case group II with a mean and standard deviation of $21.99 \pm 1.71$ and the control group with a mean and standard deviation of $22.12 \pm 1.69, \mathrm{p}=0.928$ (there was no significant difference between the three groups in BMI). In this study, all subjects from each group had a normal BMI. Because according to a study conducted by Juncal-Ruiz et al., in 2018 in Spain, the study concluded that being overweight can change the homeostasis of the immune system and therefore can cause a pro-inflammatory additive effect on those caused by psychosis in the central nervous system. ${ }^{19}$

On the demographic characteristics of the duration of illness for the case group I with a median of 3 years and a minimum of 1 year-maximum 5 years and the case group II a median of 3 years and a minimum of 1 year-a maximum of 5 years, $p=0.052$, in this study only subjects taken with the duration of illness $\leq 5$ years (there was no significant difference between the two groups in the duration of illness).

In this study, for differences in serum IL-2 levels in untreated and treated in the Batak tribes patients with schizophrenia and healthy controls, the number of subjects is 55 people each, with the mean case group I is $10.34 \pm 2.24 \mathrm{ng} / \mathrm{ml}$, the mean case group II is $5.53 \pm 1.05 \mathrm{ng} / \mathrm{ml}$, and the mean of the control group is $3.48 \pm 0.61 \mathrm{ng} / \mathrm{ml}, \mathrm{p}<0.001$. These results are following a study conducted by Zhang et al., in 2004 in Beijing (China), 
conducting clinical and experimental studies that assessed changes in serum IL-2 levels before and during treatment with risperidone $6 \mathrm{mg} /$ day and haloperidol $20 \mathrm{mg} / \mathrm{day}$, which was carried out for 12 weeks of treatment in 78 inpatients and 30 healthy controls, with the Friedman two-way ANOVA test on serum IL-2 levels showed a significant difference from healthy controls with a mean of $3.3 \pm 1.4 \mathrm{ng} / \mathrm{ml}$ and mean patients at baseline were $9.6 \pm 5.2 \mathrm{ng} / \mathrm{ml}$ and the mean after treatment was $6.7 \pm 4.6 \mathrm{ng} / \mathrm{ml}$ with $\mathrm{p}$-value $<0.003){ }^{7}$ This result is different from the study conducted by Ajami et al., in 2014 in Tehran (Iran) a case-control study to assess serum IL-2 levels in patients with schizophrenia before and after treatment with risperidone and clozapine, stating that in that study serum IL-2 levels could not be detected in serum from patients with schizophrenia as well as the control group. In other words, they concluded that the serum IL-2 levels in patients with schizophrenia did not increase and was the same as that of the control group (mean concentration of serum IL-2 levels before treatment in patients with schizophrenia and controls lower than the sensitivity of the kit). ${ }^{20}$

In this study, for the serum IL-2 levels to the PANSS score in untreated in the Batak tribe patients with schizophrenia as many as 55 subjects, there was a positive correlation with moderate correlation between serum IL-2 levels and the PANSS score in untreated in the Batak tribe patients with schizophrenia, with a value of $r$ is 0.599 and a value of $p=$ 0.001, also in treated in the Batak tribe patients with schizophrenia as many as 55 subjects, there is a positive correlation with moderate correlation between serum IL-2 levels and PANSS score in treated in the Batak tribe patients with schizophrenia, with a value of $r$ is 0.501 and a value of $p=0.001$. These results are by a study conducted by Zhang et al., in 2004 in Beijing (China), conducting clinical and experimental studies that assessed changes in serum IL-2 levels before and during treatment with risperidone and haloperidol, in 78 hospitalized patients. and 30 healthy controls, in that study found a significant correlation to the decrease in total PANSS score and changes in serum IL-2 levels before and after treatment with a value of $\mathrm{r}=0.38$ and $\mathrm{p}$-value $=0.02) .{ }^{7}$ This result is different from a study conducted by Ajami et al., in 2014 in Tehran (Iran) conducted a case-control study to assess serum IL-2 levels in patients with schizophrenia before and after treatment with risperidone and clozapine, which stated that there was no correlation between cytokine concentration and total score PANSS both before and after treatment. ${ }^{20}$

The limitation of this study is that this study was conducted with a cross-sectional design so that the results obtained are those obtained at the time of examination and there is no follow-up of these results. The advantages of this study are that from this study, it can be seen that the average normal of serum IL-2 level in healthy people compared to patients with schizophrenia so that you can find out if an increase in serum IL-2 levels is one of the markers for patients with schizophrenia.

\section{Conclusion}

There were significant differences in serum IL-2 levels in untreated and treated in the Batak tribes patients with schizophrenia and healthy controls with mean and standard deviation values in each group, namely, $10.34 \pm 2.24 \mathrm{ng} / \mathrm{ml}, 5.53 \pm 1.05 \mathrm{ng} / \mathrm{ml}$ and $3.48 \pm$ $0.61 \mathrm{ng} / \mathrm{ml}$ with p-value $<0.001$. There was also a relationship between serum IL-2 levels and the PANSS score in untreated in the Batak tribe patients with schizophrenia with a value of $r=0.599, p=0.001$. There is a relationship between serum IL-2 levels and the PANSS score in treated in the Batak tribe patients with schizophrenia with a value of $r=$ $0.501, \mathrm{p}=0.001$. 


\section{References}

[1] Sadock BJ, Sadock VA, Ruiz P. Schizophrenia. In Sadock BJ, Sadock VA, Ruiz P, editors. Kaplan \& Sadock's Synopsis of Psychiatry Behavioral Sciences/Clinical Psychiatry, 10th Edition. Tenth Edition ed. Philadelphia: Lippincott Williams \& Wilkins; 2007. p. 465-497.

[2] Reale M, Patruno A, Lutiis MAD, Pesce M, Felaco M, Di Giannantonio M, et al. Dysregulation of Chemo-Cytokine Production in Schizophrenic Patients Versus Healthy Controls. BMC Neuroscience. 2011; 12(13): p. 1-9.

[3] Paul-Samojedny M, Owczarek A, Kowalczyk M, Suchanek R, Palacz M, Kucia K, et al. Association of Interleukin 2 (IL-2), Interleukin 6 (IL-6), dan TNF-Alpha (TNF- $\alpha$ ) Gene Polymorphisms With Paranoid Schizophrenia In A Polish Population. The Journal of Neuropsychiatry and Clinical Neurosciences. 2013; 25: p. 72-82.

[4] Upthegrove R, Barnes NM. The Immune System and Schizophrenia: an Update For Clinicians. Advances in Psychiatric Treatment. 2014. 20: p. 83-91. doi: 10.1192/apt.bp.113.011452.

[5] Na KS, Jung HY, Kim YK. The Role of Pro-Inflammatory Cytokines in The Neuroinflammation and Neurogenesis of Schizophrenia. Progress in NeuroPsychopharmacology \& Biological Psychiatry. 2012; 48: p. 277-286.

[6] Kim YK, Kim L, Lee MS. Relationships Between Interleukins, Neurotransmitters, and Psychopathology in Drug-Free Male Schizophrenia. Schizophrenia Research. 2000; p. 165-175.

[7] Zhang XY, Zhou DF, Cao LY, Zhang PY, Wu GY, Shen YC. Changes in Serum Interleukin-2, -6 and -8 Levels Before and During Treatment With Risperidone and Haloperidol: Relationship to Outcome in Schizophrenia. J Clin Psychiatry. 2004; 65: p. 940-947.

[8] Tan Y, Li Y, Tan S, Wang Z, Yang FD, Cao B, Zunta-Soares GB, Soares JC, Zhang $X Y$. Increased Interleukin-2 Serum Levels Were Associated with Psychopathological Symptoms and Cognitive Deficits in Treatment-Resistant Schizophrenia. Schizophrenia Research. 2015. http://dx.doi.org/10.1016/j.schres.2015.10.038.

[9] Sastroasmoro S, Ismail S. Dasar-dasar Metodologi Penelitian Klinis. Edisi Ketiga. Jakarta. Sagung Seto. 2008.

[10] Marder SR, Davis MC. Second-Generation Antipsychotic. In Sadock BJ, Sadock VA, Ruiz P, Editors. Kaplan \& Sadock's Comprehensive Textbook of Psychiatry. Vol. I. $10^{\text {th }}$ Ed. Philadelphia: Lippincott Williams \& Wilkinsi. 2017. p. 8104-8229.

[11] Stahl SM. Essential Psychopharmacology Prescriber's Guide. Cambridge University Press. $6^{\text {th }}$ Ed. New York. 2017. p. 627-653.

[12]Dahlan MS. Besar Sampel Dalam Penelitian Kedokteran dan Kesehatan. Jakarta. Epidemiologi Indonesia. 2019.

[13]Dahlan M Sopiyudin. Langkah-Langkah Membuat Proposal Penelitian Bidang Kedokteran Dan Kesehatan. Jakarta. Sagung Seto. 2014.

[14]Dahlan MS. Statistik Untuk Kedokteran Dan Kesehatan. Jakarta: Epidemiologi Indonesia. 2014.

[15] Sadock BJ, Sadock VA. Ruiz P. Schizophrenia Spectrum and Other Psychotic Disorder. In Kaplan \& Sadock's Synopsis of Psychiatry Behavioral Sciences/Clinical Psychiatry, $11^{\text {th }}$ Edition. Philadelphia: Lippincott Williams \& Wilkins; 2015. p. 300323. 
[16]Pinho LG, Pereira A, Chaves C. Influence of Sociodemographic and Clinical Characteristics on The Quality of Life of Patients With Schizophrenia. Rev Esc Enferon USP. 2017; 51 : p. 1-7.

[17]Huang J, Chiovenda A, Shao Y, Ma H, Li H, Jo Delvecchio, Good M. Low Level of Knowledge Regarding Diagnosis and Treatment Among Inpatients with Schizophrenia in Shanghai. Neuropsychiatric Disease and Treatment. 2018 January; 14(1): p. 185-191.

[18]Bowmans C, Sonnevile CD, Mulder CL, Van Roijen LH. Employment and The Associated Impact on Quality of Life in People Diagnosed With Schizophrenia. Neuropsychiatric Disease and Treatment. 2015; 11: p. 2125-2214.

[19] Juncal-Ruiz M, Riesco-Davila L, Ortiz-Garcia de la Foz V, Ramirez-Bonilla M. The Effect of Excess Weight on Circulating Inflammatory Cytokines in Drug Naïve First Episode Psychosis Individuals. Juncal-Ruiz et al. Journal of Neuroinflammation. 2018; 15 (63): p. 1-8.

[20] Ajami A, Abedian F, Hosseini SH, Akbarian E, Alizadeh-Navaei R, Taghipour M. Serum TNF-ó, IL-10 and IL-2 in Schizophrenic Patients Before and After Treatment with Risperidone and Clozapine. Iran Journal Immunology; 2014. 11(3): p. 200-209. 